\title{
DOCUMENTOS
}

\section{GUERRA GUARANÍTICA}

\section{Cópia da Convenção celebrada entre Gomes Freire de Andrade}

e os Caciques para a suspensão de $\operatorname{armas}^{1}$

A los quatorze dias del mez de Noviembro de mil sietecentos cincoenta y quatro, en este Campo del Rio Jacui, en donde esta campado el Ilustrissimo, y Excellentissimo Señor Gomes Freire de Andrade, Governador, y Capitan General de la Capitania del Río de Enêro, y Minas Generales con las Tropas de S.M.F.: para auxiliar las de S.M.C. a fin de evacuar los siete Pueblos de la margen Oriental del Uruguai que (p. 81) se cedeu a nuestra Corona en virtud del Tratado de limites de las Conquistas vivieron à la prefencia del dicho Excellentissimo Señor General, D. Francisco Antonio Cassique del Pueblo de S. Angel, D. Christoval Acatú, y D. Bartolo Candiú, Cassiques del Pueblo de S. Luis, y D. Francisco Guacú, Corrigidor, que acabó en dicho Pueblo de S. Luiz, y por ellos fué dicho le permittiene el dicho Señor que ellos se retirassen à sus Pueblos en paz sin hazerles daño, si tan pôco seguirles, ni apriosinarlos, y a sus mugeres, y hijos pues ellos no querian guerra con los Portuguezes; y respondiendo-le el dicho señor General, y mas officiales abaxo firmados, que ellos se hallavan en este Exercito por orden de Su Soberano, aguardando, que la cavallada, y Boyada del Exercito de que es General el Señor D. Josaph de Andonaigue (p. 82) fuesse en estado de bolver a seguir el camino, que por falta de pastos fué obligado a retroceder, y que en teniendo orden del dicho señor General, como mandante, que era

1 Fonte: Marquês do Pombal. Relação abreviada da República. Porto Alegre: Martins Livreiro, 1989, p. 35-7. (1 $1^{\underline{a}}$ ed. Lisboa, 1757). 
de todo, se avançarian, por lo que nó determinavan retirarse, antes si fortificarse en el passo en que estaban: lo que oydo por los dichos cassiques, y de mas Indios, que presientes estaban, pedieron por Dios les concediesse tiempo, para su recurso, y aguardavan, que S.M.C. mas bien informado de su miserable estado, y vida aplicasse su Real Piedad con tal remedio, que serviesse de alivio a su miseria, y que caso S.M.C. y su General, no oyessen sus ruegos, y se metiesse otra vez en campaña, quedavan ciertos que los Portuguezes los seguian en cumplimiento de las Reales Ordenes de su Soberano, lo que oydo por el dicho Señor General, respondió no (p. 83) determinava perder un passo, de lo en que se hallava su Exercito; pero queriendo tener con ellos la piedad, que le rogavan, le permetia de tregoas el tiempo, que mediasse hasta que el Exercito de S.M.C. nuevamente marchasse a la Campaña siendo con las clausulas seguientes: Que se retirarian luego los cassiques con los Officiales, y soldados a sus Pueblos, y el Exercito Portuguez sin hazerles daño, ó hostilidad alguna passaria el Rio Pardo, conservandose de una parte, y otra en entera paz, hasta determinación de los dós Soberanos, Fidelissimo, y Catholico, ó bien hasta que el Exercito Hespañol folga á Campaña, porque en saliendo, el Exercito Portuguez precisamente ha de seguir las ordenes del General de Buenos Aires; y para que se nó sucite duda alguma, se declara es la Division interina del Rio de Viamann (p. 84) por el Guayba arriba hasta adonde le entra el Jacuhy, que es este en que nos allamos campados, seguiendole hasta su nacimiento por el braço que corre de Sudoeste. A lo que en esta Division de Rios queda a la parte del Norte nó passará ganado, ó Indio alguno, y siendo encontrados se poderá tomar el ganado por perdido, y castigar los Indios que fueren hallados: y de la parte del Sul nó passará Portuguez, y siendo hallado alguno ser castigado por los cassiques, y de mas Justicias de dichos Pueblos en la misma forma, excepto los que fueren mandados con cartas de una, ó otra parte, porque estos seran tratados con toda fidelidad: Y de como asi lo prometieron executar tanto el dicho Excellentisimo Señor General por su parte como los referidos cassiques por la suya lo firmaron todos, y juraron a los Santos Evangelios (p. 85) en que pusieron sus manos derechas en mano del Reverendo Padre Thomás Clarque, y yó Manoel da Sylva Neves secretario de la Expedicion que lo escrevi.

Gomes Freire de Andrade

D. Martin Joseph de Echame

D. Miguel Angelo de Blasco 
Francisco Antonio Cardoso de Menezes e Sousa Thomás Luiz Osorio

D. Christoval Acatú

Bartolomeu Candy

Francisco Antonio

Fabian Naguaeu

Santiago Pindo

\section{Legislação criada por D. João III para estimular o povoamento do Brasil $^{2}$}

Ordenou o dito senhor que daí em diante as pessoas que, por seus malefícios, segundo as ordenações, houvessem de ser degredadas para a ilha de S. Tomé, pelo mesmo tempo fossem degredadas para o Brasil.

Alvará de 31 de maio de 1535.

D. João [...] A quantos esta minha carta virem foço saber que, vendo eu como muitas pessoas dos meus reinos e senhorios andam continuamente homiziados com temor de minhas justiças por delitos que cometem, e a maior parte dos ditos homiziados se ausentam e vão viver a outros reinos, e porque hei por melhor e mais serviço de Deus, e meu, que os sobreditos fiquem antes em terras dos meus senhorios e vivam e morem nelas, especialmente na capitania da terra do Brasil de que ora fiz mercê o Pero de Góis, fidalgo de minha casa, para que ajudem a morar, pousar e aproveitar a dita terra: por estes respeitos e por alguns outros que me a isto movem, hei por bem e me apraz que daqui em diante para sempre quaisquer pessoas, de qualquer qualidade e condição que sejam, que andarem homiziados ou ausentes por quaisquer delitos que tenham cometido, não sendo por cada um destes quatro casos seguintes, o saber: heresia, traição, sodomia e moeda falsa, que estes tais, indo-se para o dito Brasil a morar e povoar a capitania do dito Pero de Góis não possam lá ser presos, acusados, nem demandados, constrangidos, nem executados por nenhuma via nem modo que seja pelos casos que cá tiverem cometido até o tempo em que [...] foram para o dito Brasil, posto que já sejam sentenciados e condenados a morte natural.

2 Fonte: Documentos do Brasil Colonial. São Paulo: Ática. 
E bem assim me apraz que se os ditos homiziados, depois de assim estarem na dita terra do Brasil [e] que nele residirem por espaço de quatro anos cumpridos e acabados, quiserem vir a meus reinos e senhorios e negociar suas coisas, que o possam fazer, trazendo certidão do dito Pero de Góis ou de qualquer outro capitão [...] e com tal certidão poderão os sobreditos andar livremente e seguros em meus reinos e senhorios, e negociarem o que quiserem por tempo de seis meses, que começarão do dia que chegarem ao porto ou lugar em que desembarcorem [...]

Carta de couto e homízio (1 de março de 1536).

Ordenou o dito senhor que os moços vadios de Lisboa, que andam na ribeira o furtar bolsas e fazer outros delitos, a primeira vez que fossem presos, se depois de soltos tornassem outra vez ser presos pelos semelhantes casos, que qualquer degredo que lhes houvesse de ser dado fosse para o Brasil.

Alvará de 6 de maio de 1536. 